\title{
Probiotic, Prebiotic, and Brain Development
}

\author{
Tomás Cerdó ${ }^{1,2}$, Alicia Ruíz ${ }^{2,3}$, Antonio Suárez ${ }^{3}$ and Cristina Campoy 1,2,4,5,* (i) \\ 1 Department of Paediatrics, School of Medicine, University of Granada, 18016 Granada, Spain; tcr@ugr.es \\ 2 EURISTIKOS Excellence Centre for Paediatric Research, Biomedical Research Centre, University of Granada, \\ 18016 Granada, Spain; aliruizrodriguez@ugr.es \\ 3 Department of Biochemistry and Molecular Biology 2, Biomedical Research Centre, University of Granada, \\ 18016 Granada, Spain; asuarez@ugr.es \\ 4 Spanish Network of Biomedical Research in Epidemiology and Public Health (CIBERESP), \\ Carlos III Institute, 18016 Granada, Spain \\ 5 Department of Paediatrics, Faculty of Medicine, University of Granada, Av. de la Investigación, 11, \\ 18016 Granada, Spain \\ * Correspondence: ccampoy@ugr.es; Tel.: +34-629-308-695
}

Received: 8 September 2017; Accepted: 10 November 2017; Published: 14 November 2017

\begin{abstract}
Recently, a number of studies have demonstrated the existence of a link between the emotional and cognitive centres of the brain and peripheral functions through the bi-directional interaction between the central nervous system and the enteric nervous system. Therefore, the use of bacteria as therapeutics has attracted much interest. Recent research has found that there are a variety of mechanisms by which bacteria can signal to the brain and influence several processes in relation to neurotransmission, neurogenesis, and behaviour. Data derived from both in vitro experiments and in vivo clinical trials have supported some of these new health implications. While recent molecular advancement has provided strong indications to support and justify the role of the gut microbiota on the gut-brain axis, it is still not clear whether manipulations through probiotics and prebiotics administration could be beneficial in the treatment of neurological problems. The understanding of the gut microbiota and its activities is essential for the generation of future personalized healthcare strategies. Here, we explore and summarize the potential beneficial effects of probiotics and prebiotics in the neurodevelopmental process and in the prevention and treatment of certain neurological human diseases, highlighting current and future perspectives in this topic.
\end{abstract}

Keywords: microbiota; prebiotics; probiotics; health; disease

\section{Introduction}

The micro-organisms that inhabit the human gastrointestinal tract (GI) have been implicated in the development and functioning of a number of basic physiological processes, such as digestion, immunity, and the maintenance of homeostasis. The GI microbiota may also play a role in multiple diseases, ranging from inflammation to obesity [1,2]. Recently, many studies have shown that gut microbiota play a very important role in the development and function of the central nervous system (CNS) through specific channels, such as metabolic, neuroendocrine, and immune pathways [3]. In particular, these researchers have found bi-directional communication between the brain and the gut microbiota, denominated the microbiota-gut-brain axis [4-6].

Although the molecular mechanisms by which the gut microbiota communicate with the brain are not yet clear, the link between both components is currently attributed to immune signals and the vagus nerve. Cellular components produced by gut microbiota, such as lipopolysaccharide (LPS), peptidoglycan, and flagellin, are recognized by pattern-recognition receptors (PRRs), such as Toll-like receptors (TLRs), NOD-like receptors (NLRs), or RIG-1-like receptors (RLRs), on epithelial and immune 
cells, producing cytokines, hormones, and other molecular signals, which will act as neurotransmitters within the CNS [7]. Several studies have found that, in the densely innervated gut, the vagus nerve is involved in the bi-directional communication of the microbiota-gut-brain axis [8,9], while others have shown vagus-independent effects $[10,11]$. Either way, a supplementing nutrition therapy with specific probiotic commensals and prebiotics can alter the excitability of enteric nervous system (ENS) sensory neurons [12-14]. Prebiotics-induced growth of probiotic members within the Bifidobacterium and Lactobacillus genera show multiple beneficial effects on host immunity and physiology [15]. Moreover, strong effects of Bifidobacterium and Lactobacillus spp. on the brain-gut axis have been reported [16].

This review summarizes current knowledge on the influence of the establishment of the gut microbiota in critical neurodevelopmental windows, and discusses recent findings on the interactions between the gut microbiota and the host's brain-gut axis communications. In addition, current research on the effects of the administration of probiotics and prebiotics in specific neurological disorders is reviewed. Finally, recommendations for future research on this topic are also discussed.

\section{Establishment of Intestinal Microbiota during Early Neurodevelopmental Windows}

Gut microbiota establish a beneficial cohabitation with the host that will prime for health later in life [17]. The assembly of the gut microbiota occurs during the first three years of life, starting from birth, where there is a rapid rate of colonization and expansion of gut bacteria dominated by Actinobacteria and Proteobacteria that shifts towards one dominated by Firmicutes and Bacteroidetes, increasing compositional diversity and stability while maturing into an adult-like state [18]. This process coincides in time with the intense synaptogenesis and pruning in the cerebral cortex during early life [18-20], ending in adolescence [21]. Therefore, perturbations of gut microbiota colonization and maturation by environmental factors may influence brain development. The dynamics of the microbial ecosystem's maturation during this critical period of CNS development is influenced by several environmental factors, such as mother-to-child bacterial transfer, mode of delivery, and type of feeding. The mother-to-child transfer of commensal bacteria in the uterus has been shown to influence an infant's immune system development [22,23]. Until recently, the idea that foetuses were sterile in the uterus and that the microbial colonization of the new-born started during and after birth had been widely accepted [24]. However, nowadays, this belief has been challenged by evidence of microbes in placenta and other tissues surrounding the foetus, such as umbilical cord blood after vaginal and caesarean birth [25-27]. Several studies have analysed the meconium of new-born babies and showed the presence of bacterial populations, including Enterococcus, Lactococcus, Escherichia, Leuconostoc, and Streptococcus, though at low levels, concluding that gut colonization occurs mainly after birth [28]. Based on these findings, prenatal probiotic intervention has been shown to modulate the expression of TLR-related genes in the placenta and foetal GI tract and to reduce atopic dermatitis $[29,30]$. Thus, prenatal and postnatal maternal oral probiotic therapy may represent an effective method of intervention to prevent pathologies such as allergy [31], atopic diseases [32], and neurodevelopmental disorders, reviewed below. Still, the origin of the microbiota colonizing the placenta is unknown and results have to be carefully interpreted, because, in samples with low microbial biomass, such as those from placenta, the risk of contamination is high when using high-throughput sequencing methods based on DNA amplification [29]. Further studies are needed to discern whether foetuses have contact with bacteria before birth or are colonized during and after parturition.

Regardless of mother-to-child transmission within the intrauterine environment, two different modes of maternal-infant transmission during delivery have been proposed: (a) horizontal, in which microbes are taken up from the environment for infants born by caesarean section; and (b) vertical, in which vaginal microbes are transferred during parturition to the infants [33]. Infants delivered by Caesarean section are more likely to suffer several diseases, such as asthma, obesity, or allergies, in adulthood [34]. Interestingly, a study carried out by Jasarevic et al. using a mouse model of early prenatal stress found that changes in the vaginal microbiome were associated with shifts in the abundance of Lactobacillus in the expression of maternal stress proteins related to vaginal 
immunity, in offspring metabolic profiles related to energy balance, and in the amino acid profiles of the developing brain [35].

The third strong environmental factor that influences an infant's gut microbial development as well as neurodevelopment is the type of feeding. In recent years, several studies have reported that breastfeeding and particularly full breastfeeding has beneficial effects on child neuropsychological development [36]. Human milk is the optimal feeding source, since it provides all the nutrition factors that an infant needs for healthy development. Human milk is not sterile, and, during breastfeeding, bacteria from mother's skin and mammary gland via maternal dendritic cells and macrophages [37] are transferred to the baby [38]. Breast-fed infants tend to contain a more uniform population of gut microbes dominated by Bifidobacterium and Lactobacillus [39], whereas formula-fed infants exhibit higher proportions of Bacteroides, Clostridium, Streptococcus, Enterobacteria, and Veillonella spp. [21]. Bacteria belonging to the Bifidobacterium genus present in human milk are early colonizers that characterize the gut microbial composition of healthy breast-fed new-born's [40] with beneficial functions for the host, such as the acceleration of the maturation of the immune response, the limitation of excessive inflammation, the improvement of the intestinal permeability, and an increase of acetate production [41]. In mice, $B$. infantis produces antidepressant-like effects and normalizes peripheral pro-inflammatory cytokine and tryptophan concentrations, both of which have been implicated in depression [42-44]. Moreover, breastfeeding has an additional role in the establishment of an infant's gut microbiota, since it contains bioactive molecules that are increasingly recognized as drivers of microbiota development and overall gut health [45]. Among the nutrients present in human milk, oligosaccharides constitute the third-most abundant class of molecules in terms of concentration after lactose and lipids. Nowadays, more than 200 different structures have been identified as human milk oligosaccharides (HMOs) [35]. HMOs can act as prebiotics, stimulating the growth of specific bacterial groups such as Staphylococci [46] and Bifidobacteria [47].

These results suggest that postnatal neurodevelopment and gut microbiota establishment co-occur, suggesting the intriguing possibility of a bi-directional regulation of each other's maturation [48]. Further studies are needed in order to clarify whether those differences in bacterial acquisition during early life lead to neurodevelopmental differences in infants.

\section{Gut Microbiota-Brain Axis}

The brain and the gut reciprocally influence each other by constant communication (Figure 1). The brain-gut-microbiota axis includes the CNS, the endocrine-immune system, the hypothalamus-pituitary-adrenal (HPA) axis, the autonomic nervous system, the ENS, and the gut microbiota [49]. This bi-directional communication enables signalling from the brain to influence motor, sensory, and secretory modalities of the GI tract, and conversely, signalling from the gut to affect brain function, most notably the hypothalamus and amygdala that are implicated in stress [50-52].

Though communication between brain and gut was realized in the middle of the nineteenth century [53], gut microorganisms had not been considered important for the development and function of the CNS or for brain diseases until recently, expanding the term to microbiome-gut-brain axis [54]. In humans, evidence of microbiome-gut-brain axis interactions have been obtained from the association of shifts in gut microbiota composition with central nervous disorders (i.e., autism spectrum disorder (ASD) and anxiety and depressive behaviours) and functional gastrointestinal disorders [54]. Most of the data demonstrating the role of the microbiota in the gut-brain axis have been obtained from germ-free animals [55]. Mice fed with prebiotics showed diminished stressor-induced anxiety-like behavior [56]. In a mouse model of ASD, Buffington et al. showed that a maternal high-fat diet reduced the number of oxytocin immunoreactive neurons in the hypothalamus and induced dysbiosis that was restored by a commensal Lactobacillus reuteri strain [57]. In a mouse model of Parkinson's disease, Sampson et al. highlighted a negative interaction in the microbiome-gut-brain axis because the absence of gut bacteria decreased aggregated misfolded $\alpha$-synuclein levels and reduced the severity of the animals' abnormal movements. The authors showed that short chain fatty acids 
(SCFA), such as acetate, propionate, and butyrate, the end products of anaerobic fermentation of dietary fibre and starch, promoted a microglia-mediated immune response and increased $\alpha$-synuclein aggregation, causing movement abnormalities [58]. Butyrate can cross the blood-brain barrier (BBB) and produce a dose-dependent increase in neuronal and glial nuclear histone $\mathrm{H} 3$ acetylation in mice due to its potential to inhibit histone deacetylation [59]. Another metabolite whose levels in the host are influenced by gut microbiota is tryptophan, the amino acid precursor of the neurotransmitter serotonin, and kynurenine, the main breakdown product of tryptophan catabolism [60]. Kynurenine intake during gestation and postnatal development, a time frame in which the maternal and offspring microbiota undergo major compositional and functional remodelling, produced neurochemical and cognitive deficits later in adulthood [61]. The prenatal inhibition of kynurenine synthesis modified hippocampal neuron morphology and changed neocortical and cerebellar protein expression that persisted into adulthood. In germ-free and in antibiotic-induced microbiota-depleted mice, despite increased circulating tryptophan levels, serotonin and kynurenin availabilities were decreased, suggesting that gut microbiota modulated kynurenin metabolism [62]. Distinct gut microbial species affect host physiology, producing diverse neuromolecules involved in mood regulation. Lactobacillus and Bifidobacterium spp. generate gamma-aminobutyric acid (GABA). Candida, Streptococcus, Escherichia, and Enterococcus spp. synthesise serotonin while Bacillus spp. produces dopamine [63].

Gut microbiota also influence the regulation of BBB integrity. The BBB is an active interface between systemic circulation and the CNS that maintains brain homeostasis by preventing the entry of potentially toxic or harmful substances and regulates the transport of nutrients and the removal of metabolites [64]. Braniste et al. (2014) [65] showed that the transplantation of gut microbiota into germ-free mice normalized BBB permeability and upregulated the expression of tight junction proteins. Therefore, gut microbiota have a key role in regulating BBB permeability, suggesting that the maternal gut microbiome influences an offspring's BBB integrity. Together with the results discussed in the previous section, these findings open an intriguing question on the mechanism by which a mother's gut microbiota cooperate in regulating BBB integrity and ultimately brain function development.

Gut microbiota have direct effects on the immune system, which constitutes another route of communication between gut microbes and the brain. The signalling molecules of the immune system, cytokines and chemokines, access the brain from the periphery via the vagus nerve or directly via the circumventricular organs [66]. The administration of rifaximin (a non-systemic, broad-spectrum antibiotic) to stressed rats increased the abundance of Lactobacillus in the ileum and the expression of the tight junction protein occludin while decreasing the expression of pro-inflammatory interleukin 17 , interleukin 6, and tumour necrosis factor $\alpha$ mRNA [67].

Since many of the above effects have been observed during early life, it is plausible that an environmentally induced dysbiosis of infants' microbiota (e.g., mode of birth, maternal transmission of a suboptimal microbiota, antibiotics) may generate altered patterns of microbial metabolites with detrimental effects in human CNS development. Further research is needed to unravel these mechanisms and develop probiotics or prebiotics therapies that shape gut microbial composition and metabolism to ultimately modulate CNS development. 


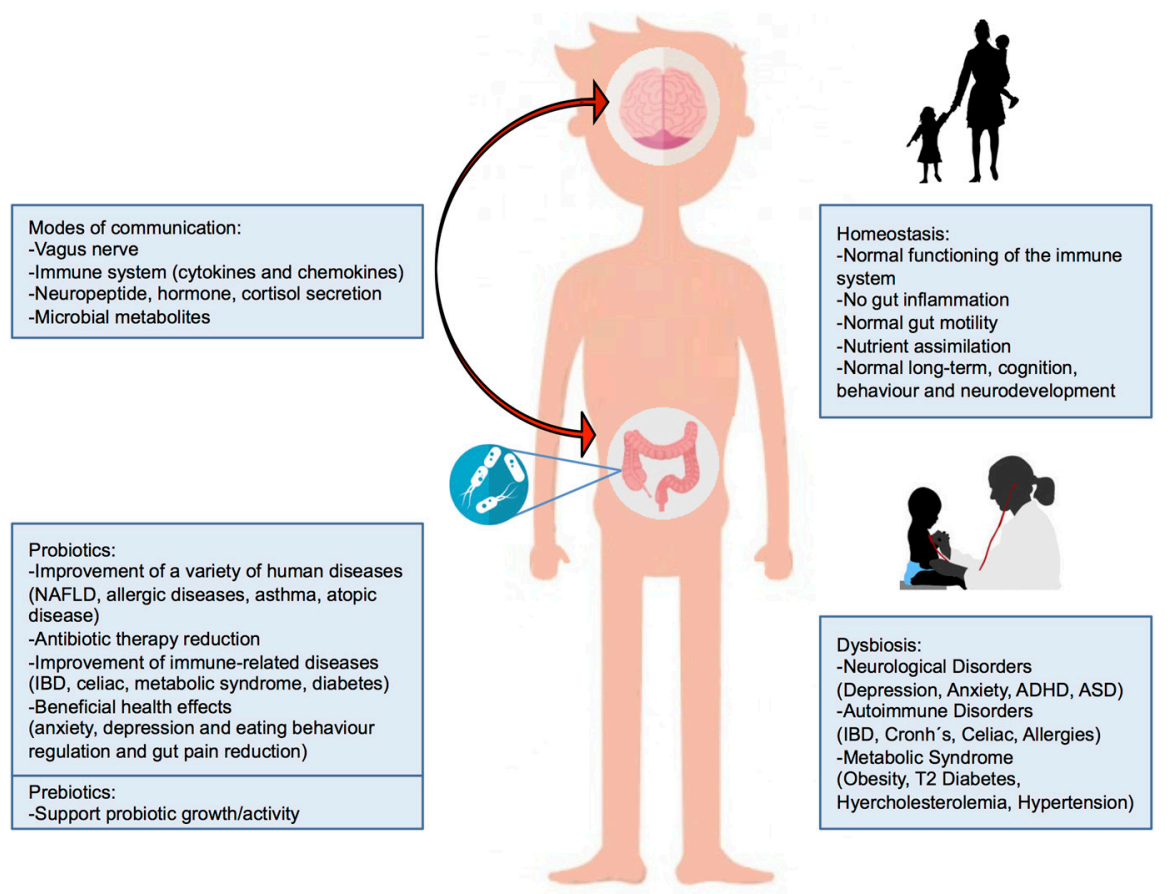

Figure 1. The gut microbiota-brain axis. The central part of the figure shows the bidirectional influence between the brain and gut microbiota. The left side of this figure shows modes of communication in the bidirectional crosstalk between gut microbiota and the brain and the possible influences of prebiotics and probiotics on human diseases. The right side of the figure shows the consequences of gut dysbiosis/homeostasis. Intestinal dysbiosis can adversely influence gut physiology, leading to inappropriate brain-gut axis signalling and associated consequences for CNS functions and disease states. Abbreviations: Non-Alcoholic Fatty Liver Disease (NAFLD), Inflammatory Bowel Disease (IBD), Attention deficit hyperactivity disorder (ADHD), Autism spectrum disorder (ASD).

\section{Probiotics}

In 2001, the Food and Agriculture Organization of the United Nations and the World Health Organization (FAO/WHO) proposed the following definition of probiotics: "live micro-organisms which, when administered in adequate amounts, confer a health benefit on the host" [68], which was reaffirmed in 2014 [69]. Probiotics, comprised by strains of Lactobacilli, Bifidobacteria and Saccharomycetes have been suggested to play a role in fighting human diseases, such as non-alcoholic fatty liver disease (NAFLD), allergy diseases, and asthma. They also promote protection against atopic disease in the infant during pregnancy and breastfeeding [32,70,71]. In addition, probiotics also reduce the duration of antibiotic therapy, and reduce symptom severity in immune-related diseases, such as inflammatory bowel diseases (IBDs), celiac disease, metabolic syndrome and diabetes [72,73].

The search for probiotics that can affect cognitive functions, known as psychobiotics, has increased in recent years (Table 1). Psychobiotics are defined as live organisms that, when ingested in adequate amounts, produce beneficial health effects to patients suffering from psychiatric illness [74]. Depression is currently a major psychiatric disorder in developed countries, and is characterized by a low mood or loss of interest and anxiety affecting appetite and sleep. Messaoudi et al. [75,76] reported a double-blind, placebo-controlled, randomized study where a multispecies probiotic containing Lactobacillus helveticus R0052 and Bifidobacterium longum R0175 (PF) was administered to healthy women for 30 days. This treatment resulted in a decrease in the global scores of the hospital anxiety and depression scale (HADs) and the global severity index of the Hopkins symptoms checklist (HSCL-90) due to the decrease of the sub-scores of somatization, depression, and anger-hostility spheres. In a cohort of 124 healthy humans, Benton et al. reported that the consumption of Lactobacillus casei-containing yogurt improved the self-reported mood of those whose mood was 
initially poor [77]. Similarly, Steenbergen et al. reported a significantly reduced overall cognitive reactivity to depression, in particular aggressive and ruminative thoughts, in forty healthy young adults that consumed either a probiotic supplement or placebo for 4 weeks [78]. Recently, Akkasheh et al. showed that the consumption of a probiotic supplement significantly decreased Beck Depression Inventory (BDI) scores, indicating overall improved symptoms, including mood, in 40 patients diagnosed with depression [79]. Conversely, Marcos et al. reported that probiotics decreased, respectively, levels of stress and anxiety assessed using the state-trait anxiety inventory (STAI) that remained unchanged in subjects under academic examination stress [80]. In a recent study carried out by Romijn et al. [81], administering a multispecies probiotic containing L. helveticus and B. longum in 79 participants that were not taking psychotropic medications at that moment and with at least moderate scores on self-report mood measures, found no evidence that the probiotic formulation was effective in treating low mood or in moderating the levels of inflammatory and other biomarkers. Improved cognitive function (neuropsychological and cognitive fatigue) was reported by Chung et al., which tested a L. helveticus-fermented milk in healthy 60-75 year olds, though no effects on stress or geriatric depression symptoms were observed [82].

Probiotics affect mood by their ability to modulate pain in the gut. A recent study reported that the administration of Lactobacillus reuteri DSM 17938 in the treatment of children with functional abdominal pain (FAP) and irritable bowel syndrome (IBS) is associated with a possible reduction of the intensity of pain [83]. In 35 patients suffering from chronic fatigue syndrome, Rao et al. showed that while the consumption of the probiotic improved anxiety scores, it had no effect on depressive symptoms [84]. Giannetti et al. also reported that a probiotic mixture of $B$. infantis M-63, B. breve M-16V, and B longum BB536 was associated with improvement in children with IBS, but not in children with functional dyspepsia (FD) [85]. In healthy women without gastrointestinal or psychiatric symptoms, the consumption of a fermented milk product containing B. animalis subsp. lactis, Streptococcus thermophilus, Lactobacillus bulgaricus, and L. lactis subsp. lactis resulted in robust alterations in activity in the brain regions that control the central processing of emotions and sensations, as observed by functional magnetic resonance imaging [86]. 
Table 1. Studies evaluating probiotics supplementation on central nervous system (CNS) disorders.

\begin{tabular}{|c|c|c|c|}
\hline Study (Reference) & Cohort Population & Probiotic Used & Key Findings \\
\hline Messaoudi et al. (2011) [75,76] & $\begin{array}{l}55 \text { healthy human volunteers plus } 25 \text { subjects with } \\
\text { urinary free cortisol (UFC) levels less than } \\
50 \mathrm{ng} / \mathrm{mL} \text { (less stressed subjects), } 10 \text { subjects } \\
\text { received the probiotic and } 15 \text { placebo. }\end{array}$ & $\begin{array}{l}\text { Lactobacillus helveticus R0052 and Bifidobacterium longum } \\
\text { R0175 (PF) }\end{array}$ & $\begin{array}{l}\text { Beneficial effects on anxiety and depression related behaviors } \\
\text { in healthy human volunteers and volunteers with lower levels } \\
\text { of cortisol }\end{array}$ \\
\hline Benton et al. (2007) [77] & $\begin{array}{l}124 \text { healthy adults volunteers were randomly } \\
\text { allocated to a group that consumed, on a daily basis, } \\
\text { a probiotic-containing milk drink or a placebo }\end{array}$ & Lactobacillus casei Shirota & $\begin{array}{l}\text { The consumption of a probiotic-containing yoghurt improved } \\
\text { the mood of those whose mood was initially poor. However, } \\
\text { there was not an increased frequency of defaecation. }\end{array}$ \\
\hline Steenbergen et al. (2015) [78] & $\begin{array}{l}40 \text { healthy young adults were randomly assigned to } \\
\text { receive a } 4 \text {-week intervention of either placebo or } \\
\text { multispecies probiotics in a triple-blind intervention } \\
\text { assessment design. }\end{array}$ & $\begin{array}{l}\text { Bifidobacterium bifidum W23, Bifidobacterium lactis W52, } \\
\text { Lactobacillus acidophilus W37, Lactobacillus brevis W63, } \\
\text { Lactobacillus casei W56, Lactobacillus salivarius W24, } \\
\text { and Lactococcus lactis (W19 and W58) }\end{array}$ & $\begin{array}{l}\text { Participants who received multispecies probiotics showed } \\
\text { a significantly reduced overall cognitive reactivity to sad mood } \\
\text { which was largely accounted for by reduced rumination and } \\
\text { aggressive thoughts. }\end{array}$ \\
\hline Akkasheh et al. (2016) [79] & $\begin{array}{l}40 \text { patients with a diagnosis of major depressive } \\
\text { disorder (MDD) whose age ranged between } 20 \text { and } \\
55 \text { years were randomized. }\end{array}$ & $\begin{array}{l}\text { Lactobacillus acidophilus, Lactobacillus casei, } \\
\text { and Bifidobacterium bifidum. }\end{array}$ & $\begin{array}{l}\text { Patients who received probiotic supplements had significantly } \\
\text { decreased Beck Depression Inventory total scores }\end{array}$ \\
\hline Marcos et al. (2004) [80] & 136 university students were randomized. & $\begin{array}{l}\text { Lactobacillus delbrueckii subsp. bulgaricus and } \\
\text { Streptococcus salivarius subsp. thermophilus plus } \\
\text { Lactobacillus casei DN-114001 }\end{array}$ & There was no significant treatment effect on anxiety. \\
\hline Romijn et al. (2017) [81] & $\begin{array}{l}79 \text { participants not currently taking psychotropic } \\
\text { medications with at least moderate scores on } \\
\text { self-report mood measures. Participants were } \\
\text { randomly allocated to receive a probiotic } \\
\text { preparation or placebo. }\end{array}$ & Lactobacillus helveticus and Bifidobacterium longum & $\begin{array}{l}\text { No significant difference was found between the probiotic and } \\
\text { placebo groups on any psychological outcome measured. }\end{array}$ \\
\hline Jadrešin et al. (2017) [83] & $\begin{array}{l}55 \text { children with age between } 4 \text { and } 18 \text { years old, } \\
\text { diagnosed as functional abdominal pain (FAP) or } \\
\text { irritable bowel syndrome (IBS) were } \\
\text { randomly allocated. }\end{array}$ & Lactobacillus reuteri DSM 17938 & $\begin{array}{l}\text { Administration of L. reuteri DSM } 17938 \text { was associated with } \\
\text { a possible reduction of the intensity of pain and significantly } \\
\text { more days without pain in children with FAP and IBS }\end{array}$ \\
\hline Giannetti et al. (2016) [85] & $\begin{array}{l}48 \text { children with IBS aged between } 8 \text { and } 17.9 \text { years } \\
\text { and } 25 \text { with functional dyspepsia (FD) with age } \\
\text { between } 8 \text { and } 16.6 \text { years were randomized. }\end{array}$ & $\begin{array}{l}\text { Bifidobacterium infantis M- } 63 \text {, breve M-16V, } \\
\text { and longum BB536 }\end{array}$ & $\begin{array}{l}\text { In children with IBS a mixture of Bifidobacteria is associated with } \\
\text { improvement in abdominal pain (AP) and quality of life (QoL). }\end{array}$ \\
\hline $\begin{array}{l}\text { Kałużna-Czaplińska et al. } \\
\text { (2012) [87] }\end{array}$ & 22 autistic children. & Lactobacillus acidophilus & $\begin{array}{l}\text { The probiotic supplementation let to a significant decrease in } \\
\text { D-arabinitol (DA) and the ratio of D-/L-arabinitol (DA/LA) } \\
\text { and to a significant improvement in ability of concentration } \\
\text { and carrying out orders }\end{array}$ \\
\hline West et al. (2013) [88] & 33 ASD children. & $\begin{array}{l}\text { Delpro }{ }^{\circledR} \text { (Lactocillus acidophilus, Lactobacillus casei, } \\
\text { Lactobacillus delbruecki, Bifidobacteria longum, } \\
\text { Bifidobacteria bifidum) }\end{array}$ & $\begin{array}{l}\text { 88\% reported a decrease in total autism treatment evaluation } \\
\text { checklist (ATEC) score, an improvement of ASD symptoms. } \\
\text { Participants also had significant improvements in all ATEC } \\
\text { domains (speech/language/communication, sociability, } \\
\text { sensory/cognitive awareness, and health/physical/behavior) }\end{array}$ \\
\hline
\end{tabular}


Table 1. Cont.

\begin{tabular}{|c|c|c|c|}
\hline Study (Reference) & Cohort Population & Probiotic Used & Key Findings \\
\hline Tomova et al. (2015) [89] & $\begin{array}{l}10 \text { children with autism, } 9 \text { siblings and } \\
10 \text { healthy children. }\end{array}$ & $\begin{array}{l}\text { "Children Dophilus" containing three strains of } \\
\text { Lactobacillus (60\%), two strains of Bifidobacterium }(25 \%) \text {, } \\
\text { and one strain of Streptococcus (15\%) }\end{array}$ & $\begin{array}{l}\text { Probiotic diet supplementation normalized the } \\
\text { Bacteroidetes / Firmicutes ratio, Desulfovibrio spp. and the amount } \\
\text { of Bifidobacterium spp. in feces of autistic children. } \\
\text { No significant difference was found to reduce symptom } \\
\text { severity in patients with autism. }\end{array}$ \\
\hline Santocchi et al. (2016) [90] & $\begin{array}{l}100 \text { preschoolers with ASD on the basis of } \\
\text { a symptom severity index specific to } \\
\text { gastrointestinal (GI) disorders. Patients with and } \\
\text { without GI disorders were blind randomized to } \\
\text { regular diet with probiotics or with placebo }\end{array}$ & $\begin{array}{l}\text { "Vivomixx }{ }^{\circledR} " \text { (one strain of Streptococcus thermophilus } \\
\text { DSM 24731, three strains of Bifidobacterium } \\
\text { (Bifidobacterium breve DSM 24732, B. longum DSM 24736, } \\
\text { B. infantis DSM 24737), and four strains of Lactobacillus } \\
\text { (Lactobacillus acidophilus DSM 24735, Lactobacillus } \\
\text { plantarum DSM 24730, Lactobacillus paracasei DSM 24733, } \\
\text { Lactobacillus delbrueckii subsp. bulgaricus DSM 24734)) }\end{array}$ & Ongoing study \\
\hline $\begin{array}{l}\text { Dickerson et al. (2014) [91] and } \\
\text { Tomasik et al. (2015) [92] }\end{array}$ & $\begin{array}{l}32 \text { patients healthy and } 33 \text { patients with } \\
\text { schizophrenia meeting DSM-IV criteria and with at } \\
\text { least moderately severe psychotic symptoms }\end{array}$ & $\begin{array}{l}\text { Lactobacillus rhamnosus strain GG and Bifidobacterium } \\
\text { animalis subsp. lactis strain Bb12 }\end{array}$ & $\begin{array}{l}\text { No significant difference was found to reduce symptom } \\
\text { severity in patients with schizophrenia. Probiotic regulate } \\
\text { immune and intestinal epithelial cells through the IL-17 family } \\
\text { of cytokines }\end{array}$ \\
\hline
\end{tabular}


Probiotics have been tested to normalize gut microbial composition and metabolism, enhance gut barrier, and relieve patients suffering from ASD. In 2012, Kaluzna-Czaplinska and Blaszczyk reported that the administration of Lactobacillus acidophilus in 22 ASD subjects decreased D-arabinitol concentration and the ratio of D-arabinitol to L-arabinitol in urine, and improved their ability to follow directions, as demonstrated through a comparison with data collected before the treatment [87]. Another study reported that a combination of Lactobacillus acidophilus, L. casei, Lactobacillus delbrueckii, B. longum and Bifidobacterium bifidum, formulated with the imunomodulator Del-Immune V (Lactobacillus rhamnosus V lysate), decreased the severity of ASD symptoms and improved GI symptoms in 33 children [88]. Moreover, a recent study of "Children Dophilus" (a combination of three species of Lactobacillus, two species of Bifidobacterium and one strain of Streptococcus) in 10 ASD children showed higher GI dysfunction in ASD children and siblings and a very strong association of the amount of Desulfovibrio spp. with the severity of autism. After the intervention, the Bacteroidetes / Firmicutes ratio, Desulfovibrio spp., and the amount of Bifidobacterium spp. were normalized in faeces of autistic children [89]. However, the effects of treatments with probiotics on children with ASD need to be evaluated through rigorous, controlled trials. In a recent clinical study currently in progress, Santocchi et al. are providing a multispecies probiotic (one strain of S. thermophilus DSM 24731, three strains of Bifidobacterium (B. breve DSM 24732, B. longum DSM 24736, and B. infantis DSM 24737), and four strains of Lactobacillus (L. acidophilus DSM 24735, Lactobacillus plantarum DSM 24730, Lactobacillus paracasei DSM 24733, and L. delbrueckii subsp. bulgaricus DSM 24734) to a group of 100 pre-schoolers with ASD. This study will try to provide new insights to clinical and neurophysiological patterns in response to a probiotic mixture in ASD patients [90].

Probiotics are also tested in the treatment of schizophrenia and bipolar disorder. One of the first trials of probiotic compounds in schizophrenia used a combined probiotic of L. rhammosus strain GG and B. animals subsp. Lactis strain Bb12. The results showed no significant difference in psychiatric symptom severity between probiotic and placebo supplementation [91]. However, other studies have found that probiotic supplementation significantly alters the levels of several serum proteins, including the von Willebrand factor and the brain-derived neurotrophic factor, and lowered the level of antibodies to the fungus Candida albicans [92,93].

Despite that the majority of the studies found positive results on symptoms in these neurological disorders, future studies are needed to identify potential probiotics for the effective modulation of these disorders as well as to define probiotics risk in therapeutic interventions. Gut microbial studies that use $16 \mathrm{~S}$ rRNA gene sequencing to characterize bacteria must consider that highly similar bacteria (higher than 97\% sequence identity) can have large differences in genomic sequences and profound differences in growth and metabolism. Hence, it is important to characterize probiotics to the strain level and apply next-generation sequencing techniques to analyse the functions encoded by their genome [94]. Therefore, the effects of one probiotic strain should not be generalized to others without confirmation in separate studies.

\section{Prebiotics}

Although the concept of a prebiotic was first defined in 1995 by Gibson, the current definition of a prebiotic is the one proposed by the International Scientific Association for Probiotics and Prebiotics (ISAPP): a substrate that is selectively utilized by host micro-organisms and confers a health benefit [95]. The group of substances recognized for their ability to influence gastrointestinal health comprise certain non-digestible oligosaccharides (NDOs), soluble fermentable fibres, and HMOs. NDOs are low molecular weight carbohydrates in nature that are intermediates between simple sugars and polysaccharides. The use of NDOs as prebiotics has rapidly increased because the enrichment of a diet with NDOs provides the opportunity to improve the gut microbial ecosystem, including bacterial populations, biochemical profiles, and physiological effects [96]. Fibre influences satiety by the following two mechanisms. One is by increasing the chewing time of fibre-rich foods, which promotes saliva and gastric acid production and increases gastric distension, triggering afferent vagal signals of 
fullness contributing to this end. The other mechanism is by slowing gastric emptying and decreasing the rate of glucose absorption in the small intestine. Consequently, the insulin response may also be attenuated; this is sometimes correlated with satiation and satiety [97]. Various hormones (i.e., ghrelin, the polypeptide $Y Y$, and the glucagon-like peptide) have been related to satiety, and are sent to the brain, where they regulate food intake and overall energy balance [98].

Though prebiotic therapies potentially could be beneficial for children with a genetic pre-disposition to develop ASD or attention deficit hyperactivity disorder because of their selective enhancement of Lactobacilli and Bifidobacteria growth [99], a small number of studies has examined the effect of these prebiotics on disorders related to CNS (Table 2). Inductive evidence that prebiotics modulated emotional satisfaction was provided by Hume et al., who investigated the effect of oligofructose-enriched inulin/d administration versus a placebo (maltodextrin) in a randomized, double-blind, placebo-controlled trial with 42 children (who were aged 7-12 and were overweight and obese) [100]. Prebiotic supplementation improved subjective appetite ratings, reducing energy intake in older but not in younger children.

In a cohort of healthy male and female subjects $(n=45)$, Schmidt et al. tested the intake of fructo-oligosaccharides (FOS) and Bimuno ${ }^{\circledR}$-galactooligosaccharides (B-GOS), and reported that only B-GOS reduced the waking-cortisol response [101]. Exaggerated waking cortisol is a biomarker of emotional disturbances, such as depression [102]. Besides this, the subjects also provided measures of vigilance, or attention to negative stimuli, which is also a behavioral marker of anxiety and depression [103]. B-GOS attenuated vigilance, suggesting a reduction in anxiety and depression [104]. Van den berg et al. found no evidence that the use of short-chain galacto-oligosaccharides/long-chain fructo-oligosaccharides/pectin-derived acidic oligosaccharides in preterm infants at 24 months improves neurodevelopmental outcomes [105]. LeCouffe et al. studied the effect of an enteral supplementation of a prebiotic mixture (neutral and acidic oligosaccharides) in the neonatal period and found no effect on neurodevelopment [106], though lower Bifidobacteria counts are associated with serious neonatal infections and lower neurodevelopmental outcomes.

More studies are required to determine whether prebiotics exert a beneficial effect on neurodevelopmental disorders in infants, and to understand the mechanism of action, by stimulating certain bacterial taxa or bacterial activities within gut microbiota. Efficacy, safety, and dosing schedules should be established for each prebiotic product in long-term follow-up studies. 
Table 2. Studies evaluating prebiotics and synbiotics supplementation on CNS disorders.

\begin{tabular}{|c|c|c|c|}
\hline Study (Reference) & Cohort Population & Prebiotic Used & Key Findings \\
\hline \multicolumn{4}{|l|}{ Prebiotics } \\
\hline Hume et al. (2017) [100] & $\begin{array}{l}42 \text { boys and girls, ages } 7-12 \text { years, with a body } \\
\text { mass index (BMI) of } \geq 85 \text { th percentile }\end{array}$ & Oligofructose-enriched inulin/d & $\begin{array}{l}\text { Prebiotic supplementation in children with overweight and obesity } \\
\text { significantly increased feelings of fullness and reduced prospective } \\
\text { food consumption in older but not in younger children }\end{array}$ \\
\hline Schmidt et al. (2105) [101] & 45 adults healthy volunteers & FOS and Bimuno ${ }^{\circledR}$-galactooligosaccharides, B-GOS & $\begin{array}{l}\text { B-GOS reduced waking-cortisol response and decreased } \\
\text { attentional vigilance to negative versus positive information }\end{array}$ \\
\hline van den Berg et al. (2016) [105] & $\begin{array}{l}77 \text { preterm infants (gestational age }<32 \text { weeks } \\
\text { and/or birth weight }<1500 \mathrm{~g} \text { ), admitted to the } \\
\text { level-III neonatal intensive care unit (NICU) }\end{array}$ & scGOS/lcFOS/pAOS & $\begin{array}{l}\text { Neurodevelopmental outcomes were not different in the } \\
\text { scGOS/lcFOS/pAOS and placebo group. Infections, lower } \\
\text { bifidobacteria counts, and higher serum cytokine levels during the } \\
\text { neonatal period were associated with lower neurodevelopmental } \\
\text { outcomes at } 24 \text { months of age }\end{array}$ \\
\hline LeCouffe et al. (2014) [106] & $\begin{array}{l}93 \text { Infants, with a gestational age (GA) of less } \\
\text { than } 32 \text { weeks and/or birth weight of less than } \\
1500 \mathrm{~g} \text {, participed in the study (prebiotic mixture } \\
\text { group }(n=48) \text { and placebo group }(n=45)\end{array}$ & $80 \% \mathrm{scGOS} / \mathrm{lcFOS}$ and $20 \% \mathrm{pAO}$ & $\begin{array}{l}\text { Short-term enteral supplementation of a prebiotic mixture in the } \\
\text { neonatal period had no effect on neurodevelopmental outcome in } \\
\text { preterm infants in the first year of life }\end{array}$ \\
\hline \multicolumn{4}{|l|}{ Synbiotics } \\
\hline Malaguarnera et al. (2007) [107] & $\begin{array}{l}60 \text { cirrhotic patients ( } 30 \text { with synbiotics and } \\
30 \text { with placebo) }\end{array}$ & Bifidobacterium longum plus fructo-oligosaccharides & $\begin{array}{l}\text { Patients with minimal hepatic encephalopathy (MHE) treated with } \\
\text { Bifidobacterium + FOS, showed an improvement and a recovery of } \\
\text { neuropsychological activities related to short-term memory, } \\
\text { attention and computing ability, language, orientation ability, } \\
\text { and cognitive activities }\end{array}$ \\
\hline Firmansyah et al. (2011) [108] & 393 healthy 12 month-old toddlers & $\begin{array}{l}\text { The probiotic Bifidobacterium longum BL999 (ATCC: BAA } \\
\text { 999) and Lactobacillus rhamonosus, LPR (CGMCC 1.3724), } \\
\text { the prebiotics inulin (30\%) and fructo-oligosaccharide } \\
\text { (70\%), and the LCPUFA, arachidonic acid (AA) and } \\
\text { docosahexaenoic acid (DHA) }\end{array}$ & $\begin{array}{l}\text { Changes in cognitive and adaptive behaviour scores between } \\
12 \text { and } 16 \text { months were higher but not significantly different in the } \\
\text { synbiotics group compared with the control group }\end{array}$ \\
\hline
\end{tabular}




\section{Synbiotics}

The term synbiotic was primarily stated considering the benefits of a product that combines prebiotics and probiotics and in which the prebiotic compounds selectively favour the probiotic strains [109]. Several studies have shown positive synergistic effects for synbiotics on obesity, diabetes, non-alcoholic fatty liver disease, necrotizing enterocolitis in very low birth weight infants, and in the treatment of hepatic encephalopathy [110-114]. Despite these findings, few studies have tested the potential benefits of synbiotics on neurodevelopmental disorders (Table 2). Malaguarnera et al. reported that $B$. longum plus FOS improved cognitive function in the treatment of minimal hepatic encephalopathy (MHE) [107]. Firmansyah et al. provided milk containing synbiotics (BL999, LPR, and prebiotics) and LCPUFA to 393 healthy toddlers at 12 months-old for 12 months. The authors reported that the change in cognitive and adaptive behaviour scores between 12 and 16 months was higher but not significantly different in the synbiotics group compared with the control group [108]. Future work is needed to determine whether synbiotics may contribute to relieve neurological diseases and to explore the benefits of new potential synbiotics during critical time windows in an infant's CNS development and susceptibility to neurological disorders.

\section{Future Perspectives}

During the last decade, numerous in vivo and in vitro studies have explored the influence of probiotics and prebiotics in host physiology [115]. Their results showed that gut microbiota may modulate inflammation, adiposity, satiety, energy expenditure, and glucose metabolism. Most efforts have focused on studying the mechanisms by which certain probiotics regulate the colonization of and protect against pathogens through the activation of the mucosal immune system and competition for limited nutrients [116,117]. Alternate approaches such as recombinant probiotics expressing therapeutic biomolecules, faecal microbiota transplantation and phage therapy, need be explored for the manipulation of the gut ecosystem. A proof of concept was the experiment performed by Paton et al., where they created a recombinant probiotic by introducing glycosyltransferase genes from Neisseria meningitidis or Campylobacter jejuni in a harmless Escherichia coli strain (CWG308) to treat and prevent the diarrheal disease caused by enterotoxigenic E. coli strains [118]. The same group also developed a recombinant probiotic for the treatment and prevention of cholera [119]. A recent study showed that microbiota transfer therapy improves ASD symptoms in children, which persists for at least 8 weeks after the treatment ends [120]. And finally, phage therapy has become an interesting strategy to treat bacterial infections due to the rise of antibioticresistant microbial strains. The only approved phage therapy clinical trial in the human gut was carried out in 120 patients with diarrhoea caused by E. coli, who were infected by a coliphage mix. The treatment failed to solve diarrhoea, although no adverse effects of phage infection were observed [121]. Customized phage cocktails could be an alternative for future therapies. These phages would directly target pre-identified bacterial pathogens though the main drawback would be the high interindividual variation of the gut microbiome and legislative approval [122,123].

In conclusion, this review summarized the accumulating evidence on the modulation of gut microbial composition and metabolism as a potential strategy for neurological disorders and CNS development. Despite this wealth of information, the effect of probiotics and prebiotics is still largely unexplored, and numerous gaps and inconsistencies exist when the studies are compared. Differences in quantity of dose, type of strain, type of prebiotic, assessment of gut microbiota, duration of intervention, standardization of neurological measurements, variety and complexity of neurological symptoms, study design, and cohort size make it difficult to confirm evidence of efficacy. To this end, double-blind placebo in vivo studies that exploit the power of the latest robust high-throughput multi-omic technologies are required to identify the molecular mechanisms of the gut's microbial modulation of neurological disorders and CNS development and ultimately to design effective probiotic and prebiotic therapies. 
Acknowledgments: This work was supported by the European Union's 7th Framework Programme under grant agreement No. 613979 (MyNewGut Project 2013/KB/613979) and by the Spanish Ministry of Economy and Competitiveness (MINECO) BFU2012-40254-C03-01. Tomás Cerdó participated in the Ph.D. Program in Biomedicine of the University of Granada and is a fellow of the FPI (BES-2013-065133) program at the Spanish Ministry of Economy and Competitiveness. This article will be part of the Ph.D. of Tomás Cerdó.

Author Contributions: T.C. and A.R. wrote the paper and contributed equally to this work. A.S. reviewed the paper and C.C. wrote, reviewed, and directed the article.

Conflicts of Interest: The authors declare no conflict of interest.

\section{References}

1. Rieder, R.; Wisniewski, P.J.; Alderman, B.L.; Campbell, S.C. Microbes and mental health: A review. Brain Behav. Immun. 2017, 66, 9-17. [CrossRef] [PubMed]

2. Cerdó, T.; Ruiz, A.; Jáuregui, R.; Azaryah, H.; Torres-Espínola, F.J.; García-Valdés, L.; Segura, M.T.; Suárez, A.; Campoy, C. Maternal obesity is associated with gut microbial metabolic potential in offspring during infancy. J. Physiol. Biochem. 2017, 1-11. [CrossRef] [PubMed]

3. Vuong, H.; Yano, J.; Fung, T.; Hsiao, E. The microbiome and host behavior. Annu. Rev. Neurosci. 2017, 40, 21-49. [CrossRef] [PubMed]

4. Ross, S.M. Microbiota-gut-brain axis, part 1: An integrated system of immunological, neural, and hormonal signals. Holist. Nurs. Pract. 2017, 31, 133-136. [PubMed]

5. Hennessey, C.H.; Sladek, J.; Miller, E.; Kim, J.; Kaur, M.; Gareau, M.G. Intestinal dysbiosis during neonatal development alters the microbiota-gut-brain axis in adulthood. FASEB J. 2017, 31, 890-895.

6. Scott, K.A.; Ida, M.; Peterson, V.L.; Prenderville, J.A.; Moloney, G.M.; Izumo, T.; Murphy, K.; Murphy, A.; Ross, R.P.; Stanton, C.; et al. Revisiting metchnikoff: Age-related alterations in microbiota-gut-brain axis in the mouse. Brain Behav. Immun. 2017, 65, 20-32. [CrossRef] [PubMed]

7. Schroeder, B.O.; Bäckhed, F. Signals from the gut microbiota to distant organs in physiology and disease. Nat. Med. 2016, 22, 1079-1089. [CrossRef] [PubMed]

8. Bravo, J.A.; Forsythe, P.; Chew, M.V.; Escaravage, E.; Savignac, H.M.; Dinan, T.G.; Bienenstock, J.; Cryan, J.F. Ingestion of lactobacillus strain regulates emotional behavior and central gaba receptor expression in a mouse via the vagus nerve. Proc. Natl. Acad. Sci. USA 2011, 108, 16050-16055. [CrossRef] [PubMed]

9. Bercik, P.; Park, A.; Sinclair, D.; Khoshdel, A.; Lu, J.; Huang, X.; Deng, Y.; Blennerhassett, P.; Fahnestock, M.; Moine, D.; et al. The anxiolytic effect of bifidobacterium longum ncc3001 involves vagal pathways for gut-brain communication. Neurogastroenterol. Motil. 2011, 23, 1132-1139. [CrossRef] [PubMed]

10. Bercik, P.; Verdu, E.F.; Foster, J.A.; Macri, J.; Potter, M.; Huang, X.; Malinowski, P.; Jackson, W.; Blennerhassett, P.; Neufeld, K.A.; et al. Chronic gastrointestinal inflammation induces anxiety-like behavior and alters central nervous system biochemistry in mice. Gastroenterology 2010, 139, 2102-2112. [CrossRef] [PubMed]

11. Bercik, P.; Denou, E.; Collins, J.; Jackson, W.; Lu, J.; Jury, J.; Deng, Y.; Blennerhassett, P.; Macri, J.; McCoy, K.D.; et al. The intestinal microbiota affect central levels of brain-derived neurotropic factor and behavior in mice. Gastroenterology 2011, 141, 599-609. [CrossRef] [PubMed]

12. Kunze, W.A.; Mao, Y.K.; Wang, B.; Huizinga, J.D.; Ma, X.; Forsythe, P.; Bienenstock, J. Lactobacillus reuteri enhances excitability of colonic ah neurons by inhibiting calcium-dependent potassium channel opening. J. Cell. Mol. Med. 2009, 13, 2261-2270. [CrossRef] [PubMed]

13. McVey Neufeld, K.; Mao, Y.; Bienenstock, J.; Foster, J.; Kunze, W. The microbiome is essential for normal gut intrinsic primary afferent neuron excitability in the mouse. Neurogastroenterol. Motil. 2013, 25, 183. [CrossRef] [PubMed]

14. Cerdó, T.; García-Valdés, L.; Altmäe, S.; Ruíz, A.; Suárez, A.; Campoy, C. Role of microbiota function during early life on child's neurodevelopment. Trends Food Sci. Technol. 2016, 57, 273-288. [CrossRef]

15. Vandenplas, Y.; Zakharova, I.; Dmitrieva, Y. Oligosaccharides in infant formula: More evidence to validate the role of prebiotics. Br. J. Nutr. 2015, 113, 1339-1344. [CrossRef] [PubMed]

16. Zhou, L.; Foster, J.A. Psychobiotics and the gut-brain axis: In the pursuit of happiness. Neuropsychiatr. Disease Treat. 2015, 11, 715. 
17. Borre, Y.E.; O'Keeffe, G.W.; Clarke, G.; Stanton, C.; Dinan, T.G.; Cryan, J.F. Microbiota and neurodevelopmental windows: Implications for brain disorders. Trends Mol. Med. 2014, 20, 509-518. [CrossRef] [PubMed]

18. Clemente, J.C.; Ursell, L.K.; Parfrey, L.W.; Knight, R. The impact of the gut microbiota on human health: An integrative view. Cell 2012, 148, 1258-1270. [CrossRef] [PubMed]

19. Tau, G.Z.; Peterson, B.S. Normal development of brain circuits. Neuropsychopharmacology 2010, 35, 147-168. [CrossRef] [PubMed]

20. Roca-Saavedra, P.; Mendez-Vilabrille, V.; Miranda, J.M.; Nebot, C.; Cardelle-Cobas, A.; Franco, C.M.; Cepeda, A. Food additives, contaminants and other minor components: Effects on human gut microbiota-a review. J. Phys. Biochem. 2017, 1-15. [CrossRef] [PubMed]

21. Jost, T.; Lacroix, C.; Braegger, C.P.; Rochat, F.; Chassard, C. Vertical mother-neonate transfer of maternal gut bacteria via breastfeeding. Environ. Microbiol. 2014, 16, 2891-2904. [CrossRef] [PubMed]

22. Rudi, K.; Avershina, E. The composition of the gut microbiota throughout life, with an emphasis on early life. Microb. Ecol. Health Dis. 2015, 26, 26050.

23. Rautava, S. Early microbial contact, the breast milk microbiome and child health. J. Dev. Orig. Health Dis. 2016, 7, 5-14. [CrossRef] [PubMed]

24. Escherich, T. The intestinal bacteria of the neonate and breast-fed infant. Rev. Infect. Dis. 1988, 10, 1220-1225. [CrossRef] [PubMed]

25. Aagaard, K.; Ma, J.; Antony, K.M.; Ganu, R.; Petrosino, J.; Versalovic, J. The placenta harbors a unique microbiome. Sci. Transl. Med. 2014, 6. [CrossRef] [PubMed]

26. Zheng, J.; Xiao, X.; Zhang, Q.; Mao, L.; Yu, M.; Xu, J. The placental microbiome varies in association with low birth weight in full-term neonates. Nutrients 2015, 7, 6924-6937. [CrossRef] [PubMed]

27. Perez-Muñoz, M.E.; Arrieta, M.-C.; Ramer-Tait, A.E.; Walter, J. A critical assessment of the "sterile womb" and "in utero colonization" hypotheses: Implications for research on the pioneer infant microbiome. Microbiome 2017, 5, 48. [CrossRef] [PubMed]

28. Mueller, N.T.; Bakacs, E.; Combellick, J.; Grigoryan, Z.; Dominguez-Bello, M.G. The infant microbiome development: Mom matters. Trends Mol. Med. 2015, 21, 109-117. [CrossRef] [PubMed]

29. Rautava, S.; Collado, M.C.; Salminen, S.; Isolauri, E. Probiotics modulate host-microbe interaction in the placenta and fetal gut: A randomized, double-blind, placebo-controlled trial. Neonatology 2012, 102, 178-184. [CrossRef] [PubMed]

30. Toh, Z.Q.; Anzela, A.; Tang, M.L.; Licciardi, P.V. Probiotic therapy as a novel approach for allergic disease. Front. Pharmacol. 2012, 3, 171. [CrossRef] [PubMed]

31. Zhang, G.-Q.; Hu, H.-J.; Liu, C.-Y.; Zhang, Q.; Shakya, S.; Li, Z.-Y. Probiotics for prevention of atopy and food hypersensitivity in early childhood: A prisma-compliant systematic review and meta-analysis of randomized controlled trials. Medicine 2016, 95, e2562. [CrossRef] [PubMed]

32. Hansen, R.; Scott, K.P.; Khan, S.; Martin, J.C.; Berry, S.H.; Stevenson, M.; Okpapi, A.; Munro, M.J.; Hold, G.L. First-pass meconium samples from healthy term vaginally-delivered neonates: An analysis of the microbiota. PLoS ONE 2015, 10, e0133320. [CrossRef] [PubMed]

33. Bright, M.; Bulgheresi, S. A complex journey: Transmission of microbial symbionts. Nat. Rev. Microbiol. 2010, 8, 218-230. [CrossRef] [PubMed]

34. Jakobsson, H.E.; Abrahamsson, T.R.; Jenmalm, M.C.; Harris, K.; Quince, C.; Jernberg, C.; Björkstén, B.; Engstrand, L.; Andersson, A.F. Decreased gut microbiota diversity, delayed bacteroidetes colonisation and reduced th1 responses in infants delivered by caesarean section. Gut 2014, 63, 559-566. [CrossRef] [PubMed]

35. Jašarević, E.; Howerton, C.L.; Howard, C.D.; Bale, T.L. Alterations in the vaginal microbiome by maternal stress are associated with metabolic reprogramming of the offspring gut and brain. Endocrinology 2015, 156, 3265-3276. [CrossRef] [PubMed]

36. Jain, A.; Concato, J.; Leventhal, J.M. How good is the evidence linking breastfeeding and intelligence? Pediatrics 2002, 109, 1044-1053. [CrossRef] [PubMed]

37. Pacheco, A.R.; Barile, D.; Underwood, M.A.; Mills, D.A. The impact of the milk glycobiome on the neonate gut microbiota. Annu. Rev. Anim. Biosci. 2015, 3, 419-445. [CrossRef] [PubMed]

38. Hunt, K.M.; Foster, J.A.; Forney, L.J.; Schütte, U.M.; Beck, D.L.; Abdo, Z.; Fox, L.K.; Williams, J.E.; McGuire, M.K.; McGuire, M.A. Characterization of the diversity and temporal stability of bacterial communities in human milk. PLoS ONE 2011, 6, e21313. [CrossRef] [PubMed] 
39. Zivkovic, A.M.; German, J.B.; Lebrilla, C.B.; Mills, D.A. Human milk glycobiome and its impact on the infant gastrointestinal microbiota. Proc. Natl. Acad. Sci. USA 2011, 108, 4653-4658. [CrossRef] [PubMed]

40. Urbaniak, C.; Cummins, J.; Brackstone, M.; Macklaim, J.M.; Gloor, G.B.; Baban, C.K.; Scott, L.; O'Hanlon, D.M.; Burton, J.P.; Francis, K.P.; et al. Microbiota of human breast tissue. Appl. Environ. Microbiol. 2014, 80, 3007-3014. [CrossRef] [PubMed]

41. Gueimonde, M.; Laitinen, K.; Salminen, S.; Isolauri, E. Breast milk: A source of bifidobacteria for infant gut development and maturation? Neonatology 2007, 92, 64-66. [CrossRef] [PubMed]

42. Underwood, M.A.; German, J.B.; Lebrilla, C.B.; Mills, D.A. Bifidobacterium longum subspecies infantis: Champion colonizer of the infant gut. Pediatr. Res. 2015, 77, 229. [CrossRef] [PubMed]

43. Desbonnet, L.; Garrett, L.; Clarke, G.; Kiely, B.; Cryan, J.; Dinan, T. Effects of the probiotic bifidobacterium infantis in the maternal separation model of depression. Neuroscience 2010, 170, 1179-1188. [CrossRef] [PubMed]

44. Desbonnet, L.; Garrett, L.; Clarke, G.; Bienenstock, J.; Dinan, T.G. The probiotic bifidobacteria infantis: An assessment of potential antidepressant properties in the rat. J. Psychiatr. Res. 2008, 43, 164-174. [CrossRef] [PubMed]

45. Maes, M.; Berk, M.; Goehler, L.; Song, C.; Anderson, G.; Gałecki, P.; Leonard, B. Depression and sickness behavior are janus-faced responses to shared inflammatory pathways. BMC Med. 2012, 10, 66. [CrossRef] [PubMed]

46. Bezirtzoglou, E.; Tsiotsias, A.; Welling, G.W. Microbiota profile in feces of breast-and formula-fed newborns by using fluorescence in situ hybridization (fish). Anaerobe 2011, 17, 478-482. [CrossRef] [PubMed]

47. Fallani, M.; Young, D.; Scott, J.; Norin, E.; Amarri, S.; Adam, R.; Aguilera, M.; Khanna, S.; Gil, A.; Edwards, C.A.; et al. Intestinal microbiota of 6-week-old infants across europe: Geographic influence beyond delivery mode, breast-feeding, and antibiotics. J. Pediatr. Gastroenterol. Nutr. 2010, 51, 77-84. [CrossRef] [PubMed]

48. Tognini, P. Gut microbiota: A potential regulator of neurodevelopment. Front. Cell. Neurosci. $2017,11$. [CrossRef] [PubMed]

49. Cong, X.; Henderson, W.A.; Graf, J.; McGrath, J.M. Early life experience and gut microbiome: The brain-gut-microbiota signaling system. Adv. Neonatal Care Off. J. Natl. Assoc. Neonatal Nurses 2015, 15, 314. [CrossRef] [PubMed]

50. Collins, S.M.; Bercik, P. Gut microbiota: Intestinal bacteria influence brain activity in healthy humans. Nat. Rev. Gastroenterol. Hepatol. 2013, 10, 326-327. [CrossRef] [PubMed]

51. Palma, G.; Collins, S.M.; Bercik, P.; Verdu, E.F. The microbiota-gut-brain axis in gastrointestinal disorders: Stressed bugs, stressed brain or both? J. Physiol. 2014, 592, 2989-2997. [CrossRef] [PubMed]

52. Collins, S.M.; Surette, M.; Bercik, P. The interplay between the intestinal microbiota and the brain. Nat. Rev. Microbiol. 2012, 10, 735-742. [CrossRef] [PubMed]

53. Cryan, J.F.; Dinan, T.G. Mind-altering microorganisms: The impact of the gut microbiota on brain and behaviour. Nat. Rev. Neurosci. 2012, 13, 701-712. [CrossRef] [PubMed]

54. Mayer, E.A.; Knight, R.; Mazmanian, S.K.; Cryan, J.F.; Tillisch, K. Gut microbes and the brain: Paradigm shift in neuroscience. J. Neurosci. 2014, 34, 15490-15496. [CrossRef] [PubMed]

55. Luczynski, P.; McVey Neufeld, K.-A.; Oriach, C.S.; Clarke, G.; Dinan, T.G.; Cryan, J.F. Growing up in a bubble: Using germ-free animals to assess the influence of the gut microbiota on brain and behavior. Int. J. Neuropsychopharmacol. 2016, 19. [CrossRef] [PubMed]

56. Tarr, A.J.; Galley, J.D.; Fisher, S.E.; Chichlowski, M.; Berg, B.M.; Bailey, M.T. The prebiotics $3^{\prime}$ sialyllactose and $6^{\prime}$ sialyllactose diminish stressor-induced anxiety-like behavior and colonic microbiota alterations: Evidence for effects on the gut-brain axis. Brain Behav. Immun. 2015, 50, 166-177. [CrossRef] [PubMed]

57. Buffington, S.A.; Di Prisco, G.V.; Auchtung, T.A.; Ajami, N.J.; Petrosino, J.F.; Costa-Mattioli, M. Microbial reconstitution reverses maternal diet-induced social and synaptic deficits in offspring. Cell 2016, 165, 1762-1775. [CrossRef] [PubMed]

58. Sampson, T.R.; Debelius, J.W.; Thron, T.; Janssen, S.; Shastri, G.G.; Ilhan, Z.E.; Challis, C.; Schretter, C.E.; Rocha, S.; Gradinaru, V.; et al. Gut microbiota regulate motor deficits and neuroinflammation in a model of parkinson's disease. Cell 2016, 167, 1469-1480. [CrossRef] [PubMed] 
59. Minamiyama, M.; Katsuno, M.; Adachi, H.; Waza, M.; Sang, C.; Kobayashi, Y.; Tanaka, F.; Doyu, M.; Inukai, A.; Sobue, G. Sodium butyrate ameliorates phenotypic expression in a transgenic mouse model of spinal and bulbar muscular atrophy. Hum. Mol. Genet. 2004, 13, 1183-1192. [CrossRef] [PubMed]

60. Slominski, A.; Semak, I.; Pisarchik, A.; Sweatman, T.; Szczesniewski, A.; Wortsman, J. Conversion of 1-tryptophan to serotonin and melatonin in human melanoma cells. FEBS Lett. 2002, 511, 102-106. [CrossRef]

61. Alexander, K.S.; Pocivavsek, A.; Wu, H.-Q.; Pershing, M.L.; Schwarcz, R.; Bruno, J.P. Early developmental elevations of brain kynurenic acid impair cognitive flexibility in adults: Reversal with galantamine. Neuroscience 2013, 238, 19-28. [CrossRef] [PubMed]

62. Khalil, O.S.; Pisar, M.; Forrest, C.M.; Vincenten, M.C.; Darlington, L.G.; Stone, T.W. Prenatal inhibition of the kynurenine pathway leads to structural changes in the hippocampus of adult rat offspring. Eur. J. Neurosci. 2014, 39, 1558-1571. [CrossRef] [PubMed]

63. Holzer, P.; Farzi, A. Neuropeptides and the microbiota-gut-brain axis. In Microbial Endocrinology: The Microbiota-Gut-Brain Axis in Health and Disease; Springer: New York, NY, USA, 2014; pp. 195-219.

64. Del Zoppo, G.J.; Mabuchi, T. Cerebral microvessel responses to focal ischemia. J. Cereb. Blood Flow Metab. 2003, 23, 879-894. [CrossRef] [PubMed]

65. Braniste, V.; Al-Asmakh, M.; Kowal, C.; Anuar, F.; Abbaspour, A.; Tóth, M.; Korecka, A.; Bakocevic, N.; $\mathrm{Ng}$, L.G.; Kundu, P.; et al. The gut microbiota influences blood-brain barrier permeability in mice. Sci. Transl. Med. 2014, 6. [CrossRef] [PubMed]

66. Sherwin, E.; Rea, K.; Dinan, T.G.; Cryan, J.F. A gut (microbiome) feeling about the brain. Curr. Opin. Gastroenterol. 2016, 32, 96-102. [CrossRef] [PubMed]

67. Xu, D.; Gao, J.; Gillilland, M.; Wu, X.; Song, I.; Kao, J.Y.; Owyang, C. Rifaximin alters intestinal bacteria and prevents stress-induced gut inflammation and visceral hyperalgesia in rats. Gastroenterology 2014, 146, 484-496. [CrossRef] [PubMed]

68. Joint, F.A.O. Who expert consultation on evaluation of health and nutritional properties of probiotics in food including powder milk with live lactic acid bacteria. Córdoba Argentina Oct. 2001, 1, 1-4.

69. Hill, C.; Guarner, F.; Reid, G.; Gibson, G.R.; Merenstein, D.J.; Pot, B.; Morelli, L.; Canani, R.B.; Flint, H.J.; Salminen, S.; et al. Expert consensus document: The international scientific association for probiotics and prebiotics consensus statement on the scope and appropriate use of the term probiotic. Nat. Rev. Gastroenterol. Hepatol. 2014, 11, 506-514. [CrossRef] [PubMed]

70. Al-muzafar, H.M.; Amin, K.A. Probiotic mixture improves fatty liver disease by virtue of its action on lipid profiles, leptin, and inflammatory biomarkers. BMC Complement. Altern. Med. 2017, 17, 43. [CrossRef] [PubMed]

71. West, C.E.; Jenmalm, M.C.; Kozyrskyj, A.L.; Prescott, S.L. Probiotics for treatment and primary prevention of allergic diseases and asthma: Looking back and moving forward. Expert Rev. Clin. Immunol. 2016, 12, 625-639. [CrossRef] [PubMed]

72. Rayes, N.; Seehofer, D.; Hansen, S.; Boucsein, K.; Müller, A.R.; Serke, S.; Bengmark, S.; Neuhaus, P. Early enteral supply of lactobacillus and fiber versus selective bowel decontamination: A controlled trial in liver transplant recipients. Transplantation 2002, 74, 123-128. [CrossRef] [PubMed]

73. Ivanov, I.I.; Honda, K. Intestinal commensal microbes as immune modulators. Cell Host Microbe 2012, 12, 496-508. [CrossRef] [PubMed]

74. Dinan, T.G.; Stanton, C.; Cryan, J.F. Psychobiotics: A novel class of psychotropic. Biol. Psychiatry 2013, 74, 720-726. [CrossRef] [PubMed]

75. Messaoudi, M.; Violle, N.; Bisson, J.-F.; Desor, D.; Javelot, H.; Rougeot, C. Beneficial psychological effects of a probiotic formulation (lactobacillus helveticus r0052 and bifidobacterium longum r0175) in healthy human volunteers. Gut Microbes 2011, 2, 256-261. [CrossRef] [PubMed]

76. Messaoudi, M.; Lalonde, R.; Violle, N.; Javelot, H.; Desor, D.; Nejdi, A.; Bisson, J.-F.; Rougeot, C.; Pichelin, M.; Cazaubiel, M.; et al. Assessment of psychotropic-like properties of a probiotic formulation (lactobacillus helveticus r0052 and bifidobacterium longum r0175) in rats and human subjects. Br. J. Nutr. 2011, 105, 755-764. [CrossRef] [PubMed]

77. Benton, D.; Williams, C.; Brown, A. Impact of consuming a milk drink containing a probiotic on mood and cognition. Eur. J. Clin. Nutr. 2007, 61, 355-361. [CrossRef] [PubMed] 
78. Steenbergen, L.; Sellaro, R.; van Hemert, S.; Bosch, J.A.; Colzato, L.S. A randomized controlled trial to test the effect of multispecies probiotics on cognitive reactivity to sad mood. Brain Behav. Immun. 2015, 48, 258-264. [CrossRef] [PubMed]

79. Akkasheh, G.; Kashani-Poor, Z.; Tajabadi-Ebrahimi, M.; Jafari, P.; Akbari, H.; Taghizadeh, M.; Memarzadeh, M.R.; Asemi, Z.; Esmaillzadeh, A. Clinical and metabolic response to probiotic administration in patients with major depressive disorder: A randomized, double-blind, placebo-controlled trial. Nutrition 2016, 32, 315-320. [CrossRef] [PubMed]

80. Marcos, A.; Wärnberg, J.; Nova, E.; Gómez, S.; Alvarez, A.; Alvarez, R.; Mateos, J.A.; Cobo, J.M. The effect of milk fermented by yogurt cultures plus lactobacillus casei dn-114001 on the immune response of subjects under academic examination stress. Eur. J. Nutr. 2004, 43, 381-389. [CrossRef] [PubMed]

81. Romijn, A.R.; Rucklidge, J.J.; Kuijer, R.G.; Frampton, C. A double-blind, randomized, placebo-controlled trial of lactobacillus helveticus and bifidobacterium longum for the symptoms of depression. Aust. N. Z. J. Psychiatry 2017. [CrossRef] [PubMed]

82. Chung, Y.-C.; Jin, H.-M.; Cui, Y.; Kim, D.S.; Jung, J.M.; Park, J.-I.; Jung, E.-S.; Choi, E.-K.; Chae, S.-W. Fermented milk of lactobacillus helveticus idcc3801 improves cognitive functioning during cognitive fatigue tests in healthy older adults. J. Funct. Foods 2014, 10, 465-474. [CrossRef]

83. Jadrešin, O.; Hojsak, I.; Mišak, Z.; Kekez, A.J.; Trbojevic, T.; Ivkovic, L.; Kolacek, S. Lactobacillus reuteri dsm 17938 in the treatment of functional abdominal pain in children: Rct study. J. Pediatr. Gastroenterol. Nutr. 2017, 64, 925-929. [CrossRef] [PubMed]

84. Rao, A.V.; Bested, A.C.; Beaulne, T.M.; Katzman, M.A.; Iorio, C.; Berardi, J.M.; Logan, A.C. A randomized, double-blind, placebo-controlled pilot study of a probiotic in emotional symptoms of chronic fatigue syndrome. Gut Pathog. 2009, 1, 6. [CrossRef] [PubMed]

85. Giannetti, E.; Maglione, M.; Alessandrella, A.; Strisciuglio, C.; De Giovanni, D.; Campanozzi, A.; Miele, E.; Staiano, A. A mixture of 3 bifidobacteria decreases abdominal pain and improves the quality of life in children with irritable bowel syndrome: A multicenter, randomized, double-blind, placebo-controlled, crossover trial. J. Clin. Gastroenterol. 2017, 51, e5-e10. [CrossRef] [PubMed]

86. Tillisch, K.; Labus, J.; Kilpatrick, L.; Jiang, Z.; Stains, J.; Ebrat, B.; Guyonnet, D.; Legrain-Raspaud, S.; Trotin, B.; Naliboff, B.; et al. Consumption of fermented milk product with probiotic modulates brain activity. Gastroenterology 2013, 144, 1394-1401. [CrossRef] [PubMed]

87. Kałużna-Czaplińska, J.; Błaszczyk, S. The level of arabinitol in autistic children after probiotic therapy. Nutrition 2012, 28, 124-126. [CrossRef] [PubMed]

88. West, R.; Roberts, E.; Sichel, L.; Sichel, J. Improvements in gastrointestinal symptoms among children with autism spectrum disorder receiving the delpro®probiotic and immunomodulator formulation. J. Prob. Health 2013, 1, 2 .

89. Tomova, A.; Husarova, V.; Lakatosova, S.; Bakos, J.; Vlkova, B.; Babinska, K.; Ostatnikova, D. Gastrointestinal microbiota in children with autism in slovakia. Physiol. Behav. 2015, 138, 179-187. [CrossRef] [PubMed]

90. Santocchi, E.; Guiducci, L.; Fulceri, F.; Billeci, L.; Buzzigoli, E.; Apicella, F.; Calderoni, S.; Grossi, E.; Morales, M.A.; Muratori, F. Gut to brain interaction in autism spectrum disorders: A randomized controlled trial on the role of probiotics on clinical, biochemical and neurophysiological parameters. BMC Psychiatry 2016, 16, 183. [CrossRef] [PubMed]

91. Dickerson, F.B.; Stallings, C.; Origoni, A.; Katsafanas, E.; Savage, C.L.; Schweinfurth, L.A.; Goga, J.; Khushalani, S.; Yolken, R.H. Effect of probiotic supplementation on schizophrenia symptoms and association with gastrointestinal functioning: A randomized, placebo-controlled trial. Prim. Care Companion CNS Disord. 2014, 16. [CrossRef] [PubMed]

92. Tomasik, J.; Yolken, R.H.; Bahn, S.; Dickerson, F.B. Immunomodulatory effects of probiotic supplementation in schizophrenia patients: A randomized, placebo-controlled trial. Biomark. Insights 2015, 10, 47. [CrossRef] [PubMed]

93. Severance, E.G.; Gressitt, K.L.; Stallings, C.R.; Katsafanas, E.; Schweinfurth, L.A.; Savage, C.L.; Adamos, M.B.; Sweeney, K.M.; Origoni, A.E.; Khushalani, S.; et al. Candida albicans exposures, sex specificity and cognitive deficits in schizophrenia and bipolar disorder. NPJ Schizophr. 2016, 2, 16018. [CrossRef] [PubMed]

94. Culligan, E.P.; Hill, C.; Sleator, R.D. Probiotics and gastrointestinal disease: Successes, problems and future prospects. Gut Pathog. 2009, 1, 19. [CrossRef] [PubMed] 
95. Gibson, G.R.; Hutkins, R.W.; Sanders, M.E.; Prescott, S.L.; Reimer, R.A.; Salminen, S.J.; Scott, K.; Stanton, C.; Swanson, K.S.; Cani, P.D. The international scientific association for probiotics and prebiotics (isapp) consensus statement on the definition and scope of prebiotics. Nat. Rev. Gastroenterol. Hepatol. 2017. [CrossRef] [PubMed]

96. Mussatto, S.I.; Mancilha, I.M. Non-digestible oligosaccharides: A review. Carbohydr. Polym. 2007, 68, 587-597. [CrossRef]

97. Slavin, J. Fiber and prebiotics: Mechanisms and health benefits. Nutrients 2013, 5, 1417-1435. [CrossRef] [PubMed]

98. Page, A.; Kentish, S. Plasticity of gastrointestinal vagal afferent satiety signals. Neurogastroenterol. Motil. 2016. [CrossRef] [PubMed]

99. Theije, C.G.; Bavelaar, B.M.; Lopes da Silva, S.; Korte, S.M.; Olivier, B.; Garssen, J.; Kraneveld, A.D. Food allergy and food-based therapies in neurodevelopmental disorders. Pediatr. Allergy Immunol. 2014, 25, 218-226. [CrossRef] [PubMed]

100. Hume, M.P.; Nicolucci, A.C.; Reimer, R.A. Prebiotic supplementation improves appetite control in children with overweight and obesity: A randomized controlled trial. Am. J. Clin. Nutr. 2017, 105, 790-799. [CrossRef] [PubMed]

101. Schmidt, K.; Cowen, P.J.; Harmer, C.J.; Tzortzis, G.; Errington, S.; Burnet, P.W. Prebiotic intake reduces the waking cortisol response and alters emotional bias in healthy volunteers. Psychopharmacology 2015, 232, 1793-1801. [CrossRef] [PubMed]

102. Mannie, Z.N.; Harmer, C.J.; Cowen, P.J. Increased waking salivary cortisol levels in young people at familial risk of depression. Am. J. Psychiatry 2007, 164, 617-621. [CrossRef] [PubMed]

103. Beck, A.T. Cognitive Therapy and the Emotional Disorders; Penguin: London, UK, 1979.

104. Ironside, M.; O'Shea, J.; Cowen, P.J.; Harmer, C.J. Frontal cortex stimulation reduces vigilance to threat: Implications for the treatment of depression and anxiety. Biol. Psychiatry 2016, 79, 823-830. [CrossRef] [PubMed]

105. Van den Berg, J.P.; Westerbeek, E.A.; Bröring-Starre, T.; Garssen, J.; van Elburg, R.M. Neurodevelopment of preterm infants at 24 months after neonatal supplementation of a prebiotic mix: A randomized trial. J. Pediatr. Gastroenterol. Nutr. 2016, 63, 270-276. [CrossRef] [PubMed]

106. LeCouffe, N.E.; Westerbeek, E.A.; van Schie, P.E.; Schaaf, V.A.; Lafeber, H.N.; van Elburg, R.M. Neurodevelopmental outcome during the first year of life in preterm infants after supplementation of a prebiotic mixture in the neonatal period: A follow-up study. Neuropediatrics 2014, 45, 022-029. [CrossRef] [PubMed]

107. Malaguarnera, M.; Greco, F.; Barone, G.; Gargante, M.P.; Malaguarnera, M.; Toscano, M.A. Bifidobacterium longum with fructo-oligosaccharide (fos) treatment in minimal hepatic encephalopathy: A randomized, double-blind, placebo-controlled study. Dig. Dis. Sci. 2007, 52, 3259. [CrossRef] [PubMed]

108. Firmansyah, A.; Dwipoerwantoro, P.G.; Kadim, M.; Alatas, S.; Conus, N.; Lestarina, L.; Bouisset, F.; Steenhout, P. Improved growth of toddlers fed a milk containing synbiotics. Asia Pac. J. Clin. Nutr. 2011, 20, 69-76. [PubMed]

109. Schrezenmeir, J.; de Vrese, M. Probiotics, prebiotics, and synbiotics-Approaching a definition. Am. J. Clin. Nutr. 2001, 73, 361s-364s. [PubMed]

110. Islek, A.; Sayar, E.; Yilmaz, A.; Baysan, B.O.; Mutlu, D.; Artan, R. The role of bifidobacterium lactis b94 plus inulin in the treatment of acute infectious diarrhea in children. Turk. J. Gastroenterol. 2014, 25, 628-633. [CrossRef] [PubMed]

111. Asemi, Z.; Khorrami-Rad, A.; Alizadeh, S.-A.; Shakeri, H.; Esmaillzadeh, A. Effects of synbiotic food consumption on metabolic status of diabetic patients: A double-blind randomized cross-over controlled clinical trial. Clin. Nutr. 2014, 33, 198-203. [CrossRef] [PubMed]

112. Steed, H.; Macfarlane, G.T.; Blackett, K.L.; Bahrami, B.; Reynolds, N.; Walsh, S.V.; Cummings, J.H.; Macfarlane, S. Clinical trial: The microbiological and immunological effects of synbiotic consumption-A randomized double-blind placebo-controlled study in active crohn's disease. Aliment. Pharmacol. Ther. 2010, 32, 872-883. [CrossRef] [PubMed]

113. Dilli, D.; Aydin, B.; Fettah, N.D.; Özyazıcı, E.; Beken, S.; Zenciroğlu, A.; Okumuş, N.; Özyurt, B.M.; İpek, M.Ş.; Akdağ, A. The propre-save study: Effects of probiotics and prebiotics alone or combined on necrotizing enterocolitis in very low birth weight infants. J. Pediatr. 2015, 166, 545-551. [CrossRef] [PubMed] 
114. Eslamparast, T.; Poustchi, H.; Zamani, F.; Sharafkhah, M.; Malekzadeh, R.; Hekmatdoost, A. Synbiotic supplementation in nonalcoholic fatty liver disease: A randomized, double-blind, placebo-controlled pilot study. Am. J. Clin. Nutr. 2014, 99, 535-542. [CrossRef] [PubMed]

115. Daliri, E.B.-M.; Lee, B.H. New perspectives on probiotics in health and disease. Food Sci. Hum. Wellness 2015, 4, 56-65. [CrossRef]

116. Kamada, N.; Chen, G.Y.; Inohara, N.; Núñez, G. Control of pathogens and pathobionts by the gut microbiota. Nat. Immunol. 2013, 14, 685-690. [CrossRef] [PubMed]

117. Christensen, K.V.; Morch, M.G.; Morthorst, T.H.; Lykkemark, S.; Olsen, A. Microbiota, probiotic bacteria and ageing. In Ageing: Lessons from C. elegans; Springer: New York, NY, USA, 2017; pp. 411-429.

118. Paton, A.W.; Jennings, M.P.; Morona, R.; Wang, H.; Focareta, A.; Roddam, L.F.; Paton, J.C. Recombinant probiotics for treatment and prevention of enterotoxigenic escherichia coli diarrhea. Gastroenterology 2005, 128, 1219-1228. [CrossRef] [PubMed]

119. Focareta, A.; Paton, J.C.; Morona, R.; Cook, J.; Paton, A.W. A recombinant probiotic for treatment and prevention of cholera. Gastroenterology 2006, 130, 1688-1695. [CrossRef] [PubMed]

120. Kang, D.-W.; Adams, J.B.; Gregory, A.C.; Borody, T.; Chittick, L.; Fasano, A.; Khoruts, A.; Geis, E.; Maldonado, J.; McDonough-Means, S. Microbiota transfer therapy alters gut ecosystem and improves gastrointestinal and autism symptoms: An open-label study. Microbiome 2017, 5, 10. [CrossRef] [PubMed]

121. Sarker, S.A.; Sultana, S.; Reuteler, G.; Moine, D.; Descombes, P.; Charton, F.; Bourdin, G.; McCallin, S.; Ngom-Bru, C.; Neville, T.; et al. Oral phage therapy of acute bacterial diarrhea with two coliphage preparations: A randomized trial in children from bangladesh. EBioMedicine 2016, 4, 124-137. [CrossRef] [PubMed]

122. Mirzaei, M.K.; Maurice, C.F. Menage a trois in the human gut: Interactions between host, bacteria and phages. Nat. Rev. Microbiol. 2017, 15, 397-408. [CrossRef] [PubMed]

123. Cooper, C.J.; Mirzaei, M.K.; Nilsson, A.S. Adapting drug approval pathways for bacteriophage-based therapeutics. Front. Microbiol. 2016, 7. [CrossRef] [PubMed]

(C) 2017 by the authors. Licensee MDPI, Basel, Switzerland. This article is an open access article distributed under the terms and conditions of the Creative Commons Attribution (CC BY) license (http:// creativecommons.org/licenses/by/4.0/). 